Received: 2018.03.09 Accepted: 2018.05.17 Published: 2018.07.24

\title{
Dengue Cerebellitis: A Case Report and Literature Review
}

Authors' Contribution: Study Design A Data Collection B Statistical Analysis C Data Interpretation D Manuscript Preparation E Literature Search F Funds Collection G

Corresponding Author: Conflict of interest:

\author{
ABCDEF Ching Soong Khoo
}

Department of Medicine, Universiti Kebangsaan Malaysia Medical Center, Cheras, Malaysia

Ching Soong Khoo, e-mail: chingsoongkhoo@gmail.com

None declared

Patient: Male, 60

Final Diagnosis: Dengue cerebellitis

Symptoms: Dizziness $\bullet$ fever $\bullet$ headaches $\bullet$ vomiting

Medication:

Lumbar puncture

Specialty: Neurology

Objective: Unusual clinical course

Background: Dengue-associated neurological manifestations have recently been on the rise. Cerebellar syndrome complicating dengue fever has rarely been reported in the literature. We present a case report of dengue-associated cerebellar syndrome and performed a literature review to draw attention to this rare neurological complication.

Case Report: $\quad$ A 60-year-old man presented with 4 days of fever, myalgia, arthralgia, headaches, and warning symptoms (persistent diarrhea and vomiting). He was admitted with serologically-confirmed dengue fever. He had been well until day 8 of illness, when he developed cerebellar signs and symptoms. The temporal relationship with the recent dengue fever suggested that he had dengue cerebellitis. He recovered well, with no neurological sequelae upon our clinic visit.

Conclusions: Dengue cerebellitis is a rare but recognized manifestation, which should be considered in patients from endemic areas of dengue fever who develop cerebellar syndrome.

MeSH Keywords: Ataxia - Cerebellar Diseases • Dengue

Full-text PDF: https://www.amjcaserep.com/abstract/index/idArt/909884

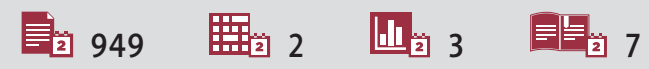




\section{Background}

The incidence of dengue fever has grown exponentially around the globe in recent years. In Malaysia, dengue fever is a public health threat due to its alarming rise in morbidity and mortality rates. At present, there are 18688 confirmed patients with dengue infection in Malaysia and 201 have died due to dengue [1]. With the escalating trend of dengue infection, atypical manifestations of dengue fever, such as dengue encephalitis, are also increasingly reported. We report a case of a diabetic patient with cerebellitis associated with dengue fever. Our literature review identified only 4 other similar cases, all from Sri Lanka. Our report underscores the importance of recognizing this rare neurological syndrome associated with dengue fever.

\section{Case Report}

A 60-year-old man presented to the Emergency Department with 4 days of fever, myalgia, arthralgia, headaches, and dengue warning symptoms (persistent diarrhea and vomiting). He lived in a dengue-prone area. He was on treatment for his type II diabetes mellitus, hypertension, dyslipidemia, and a previous stroke. He had presented with left upper limb weakness 5 years ago, which resolved within a few days. He could not recall his brain computed tomography (CT) results and had remained well with modified Rankin scale (mRS) of 0/6 upon discharge. His presenting vital signs, including glucose level, were stable. Apart from petechiae in his lower limbs, his physical examination was unremarkable. Full blood count revealed hemoglobin $15.1 \mathrm{~g} / \mathrm{dL}$, hematocrit $43 \%$, white blood cell $3.3 \times 10^{9} / \mathrm{L}$, and platelet $81 \times 10^{9} / \mathrm{L}$. His alanine transaminase was $59 \mathrm{U} / \mathrm{L}$. Renal profile was normal. Dengue IgM was detected on day 5 of illness. Blood films for malarial parasites were repeatedly negative. A diagnosis of dengue fever was made and he was managed with intravenous fluids in the ward in view of his warning symptoms. A series of full blood count monitoring is summarized in Table 1.

He was well in the ward until day 8 of illness (in recovery phase). He suddenly complained of headaches, giddiness, and vomiting.
On examination, he had nystagmus in all directions, bilateral dysmetria more prominent on the left and ataxic gait. His blood pressure was 150-160/80-90 mmHg during this acute episode. A preliminary diagnosis of acute brainstem stroke was entertained given his background of multiple underlying illnesses. The magnetic resonance imaging (MRI) of his brain revealed hyperintense signals at the right corona radiata and left frontal lobe in keeping with old stroke (Figures 1, 2). No abnormal signals were seen in his cerebellum, cerebellopontine angle, midbrain, and pons (Figure 3 ). His magnetic resonance angiogram (MRA) study was normal. Lumbar puncture was done and his cerebrospinal fluids (CSF) showed normal opening pressure, cell count, and biochemistry. Dengue PCR (sent on day 9 of illness) was not detected from his CSF. Haemophilus influenzae, Neisseria meningitidis, and Streptococcus pneumoniae were not isolated from the CSF. Antigens of Cytomegalovirus, Epstein-Barr virus, herpes simplex virus 1 and 2, and varicella zoster virus were not detected by polymerase chain reaction (PCR) from his CSF. He tested negative from his serum for HIV, hepatitis, syphilis, varicella zoster, Epstein-Barr, herpes simplex, and mycoplasma.

He was managed with physiotherapy and rehabilitation therapy in the ward for 2 weeks. He was discharged with a walking frame. Twenty days after discharge, he could walk independently and all neurological signs resolved spontaneously.

\section{Discussion}

Dengue fever is a mosquito-borne viral disease transmitted principally by the mosquito Aedes aegypti. Dengue virus is a single-stranded RNA virus with 4 serological types [2]. The clinical manifestations of dengue fever are varied, ranging from self-limited infection to plasma leakage, hemorrhage, shock, or organ failure resulting in death. Atypical syndromes are increasingly recognized, such as neurological manifestations, myocarditis, acute kidney injury and cholecystitis [3].

According to Carod-Artal et al. [4], dengue fever can manifest with neurological features ranging from $0.5 \%$ to $21 \%$ of the cases presenting at hospital. Neurological manifestations

Table 1. Full blood count trend in the ward.

Day of illness

Day 4

Day 5

Day 6

Day 7

Day 8

Day 9
Hemoglobin (g/dL)

15.1

13.7

14.6

14.3

15.8

14.2
Hematocrit (\%)

White cell $\left(10^{9} / \mathrm{L}\right)$

Platelet $\left(10^{9} / \mathrm{L}\right)$

\begin{tabular}{|ccc}
\hline 43 & 3.3 & 81 \\
\hline 41.6 & 3.0 & 53 \\
\hline 42.4 & 4.3 & 34 \\
\hline 41.3 & 7.1 & 66 \\
\hline 45.8 & 8.9 & 92 \\
\hline 40.9 & 7.5 & 148 \\
\hline
\end{tabular}




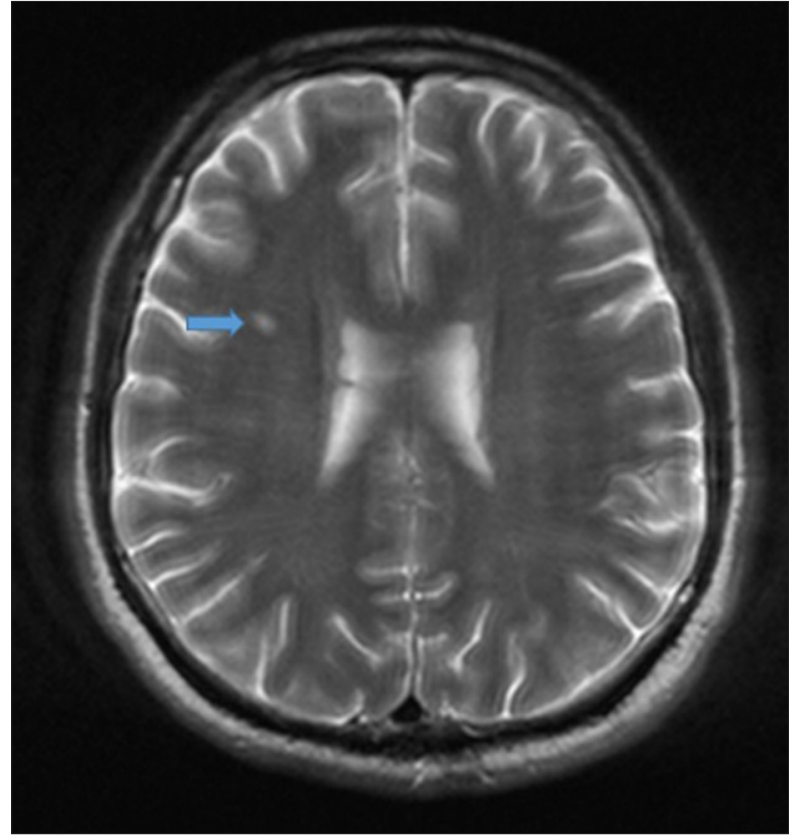

Figure 1. T2-weighted brain magnetic resonance imaging (MRI) reveals a hyperintense lesion in the right corona radiata (blue arrow)

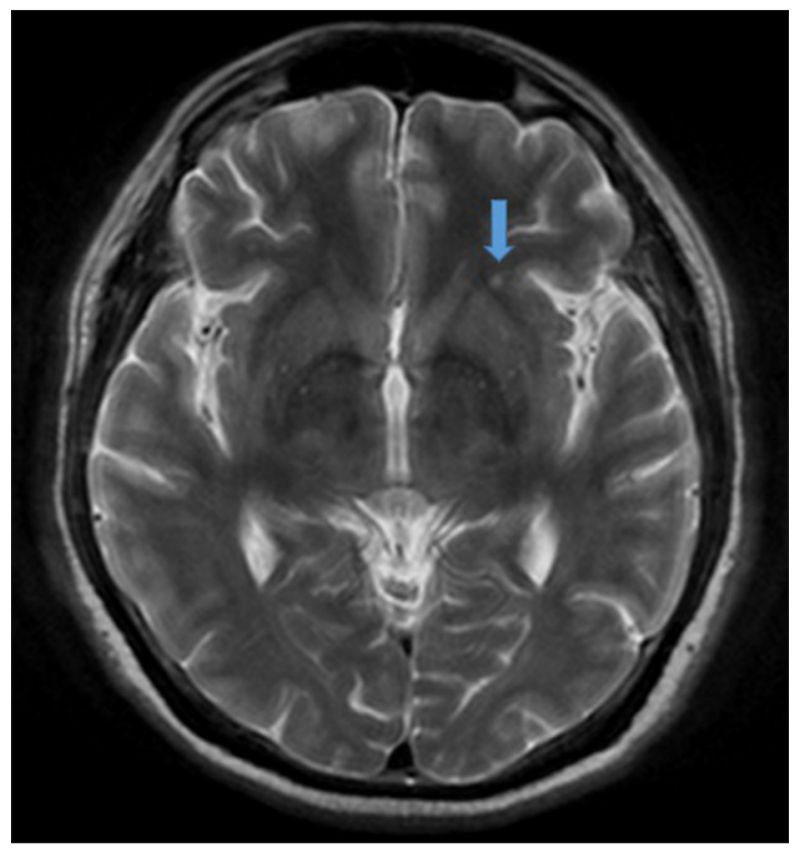

Figure 2. T2-weighted brain magnetic resonance imaging (MRI) reveals a hyperintense lesion in the left frontal lobe (blue arrow).

associated with dengue fever can broadly be classified into encephalopathy, encephalitis, neuromuscular, and neuro-ocular complications. Among these manifestations, encephalopathy, encephalitis, Guillain-Barré syndrome, myositis, and maculopathy are commonly reported.

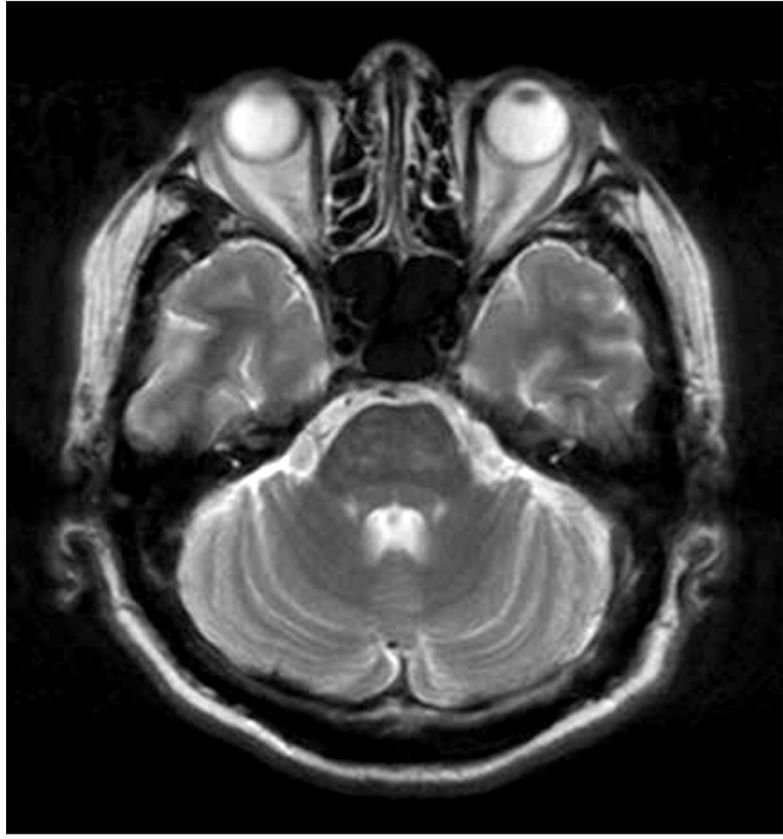

Figure 3. No abnormal signal intensity in the cerebellum in the T2-weighted brain magnetic resonance imaging (MRI).

Cerebellar syndrome associated with dengue infection was first reported by Weeratunga et al. [5] as a case series in 2013 followed by Withana et al. [6] as a case report in 2014. Our case (the fifth case) and the literature review demonstrate that patients with dengue cerebellar syndrome tend to recover spontaneously without permanent neurological sequelae. The onset of symptoms ranged from 2 days to 2 weeks. Ataxia and bilateral nystagmus were present in all cases. Cerebellar signs resolved from 1 week to 2 months. It is noteworthy that there were no changes in the neuroimaging in all but 1 case. This may suggest a transient inflammation in dengue cerebellitis. Other differences are illustrated in Table 2.

The pathogenesis of neurological syndromes remains to be elucidated. Direct invasion of the virus and immune-mediated mechanisms are postulated to cause the neurological sequelae.

Several viral infections are reported to cause cerebellitis, such as varicella zoster, Epstein-Barr, herpes simplex, measles, HIV, and coxsackie [7]. Cerebellitis can be primary infective, postinfective, or post-vaccination. Among the 5 cases, 4 (including ours) are likely primary infective and 1 is likely post-infective.

\section{Conclusions}

Dengue-related cerebellitis, although rarely reported, is a recognized neurological manifestation. Clinicians should consider dengue infection as an etiology in patients with fever who live in endemic areas and develop cerebellar syndrome. 
Table 2. Summary of the 5 cases of dengue cerebellar syndrome.

\begin{tabular}{|c|c|c|c|c|c|c|c|c|}
\hline & Age & Sex & $\begin{array}{c}\text { Phase of } \\
\text { presentation }\end{array}$ & $\begin{array}{l}\text { Cerebellar } \\
\text { signs }\end{array}$ & $\begin{array}{l}\text { Dengue } \\
\text { serology }\end{array}$ & $\begin{array}{c}\text { Brain } \\
\text { MRI }\end{array}$ & $\begin{array}{c}\text { CSF } \\
\text { analysis }\end{array}$ & $\begin{array}{c}\text { Duration of } \\
\text { complete } \\
\text { recovery }\end{array}$ \\
\hline $\begin{array}{l}\text { Weeratunga } \\
\text { et al. }\end{array}$ & 40 & Female & Critical & $\begin{array}{l}\text { Dysarthria, bilateral } \\
\text { nystagmus, } \\
\text { bilateral limb and } \\
\text { gait ataxia }\end{array}$ & $\begin{array}{l}\text { IgM positive } \\
\text { (both serum } \\
\text { and CSF) }\end{array}$ & Normal & Normal & 2 months \\
\hline $\begin{array}{l}\text { Weeratunga } \\
\text { et al. }\end{array}$ & 28 & Male & $\begin{array}{l}\text { Post } \\
\text { recovery }\end{array}$ & $\begin{array}{l}\text { Bilateral vertical } \\
\text { and horizontal } \\
\text { nystagmus, gait } \\
\text { ataxia }\end{array}$ & $\begin{array}{l}\text { IgM positive } \\
\text { (both serum } \\
\text { and CSF) }\end{array}$ & Normal & Normal & 1 week \\
\hline $\begin{array}{l}\text { Weeratunga } \\
\text { et al. }\end{array}$ & 25 & Male & Febrile & $\begin{array}{l}\text { Bilateral nystagmus, } \\
\text { dysmetria, severe } \\
\text { ataxia }\end{array}$ & $\begin{array}{l}\text { IgM positive } \\
\text { (both serum } \\
\text { and CSF) }\end{array}$ & $\begin{array}{l}\text { Bilateral and } \\
\text { symmetrical T2 } \\
\text { hyperintense } \\
\text { lesions in the } \\
\text { cerebellum }\end{array}$ & Normal & 2 weeks \\
\hline $\begin{array}{l}\text { Withana } \\
\text { et al. }\end{array}$ & 45 & Female & Febrile & $\begin{array}{l}\text { Scanning dysarthria, } \\
\text { horizontal } \\
\text { nystagmus, } \\
\text { bilateral dysmetria, } \\
\text { dysdiadochokine- } \\
\text { sia more prominent } \\
\text { on the right, ataxia, } \\
\text { tendency to fall to } \\
\text { the right }\end{array}$ & $\begin{array}{l}\text { NS } 1 \text { Antigen } \\
\text { and IgM } \\
\text { positive } \\
\text { (serum) }\end{array}$ & Normal & $\begin{array}{l}\text { Not } \\
\text { done }\end{array}$ & 17 days \\
\hline Khoo & 60 & Male & Recovery & $\begin{array}{l}\text { Nystagmus in all } \\
\text { directions, bilateral } \\
\text { dysmetria more } \\
\text { prominent on the } \\
\text { left, ataxia }\end{array}$ & $\begin{array}{l}\text { IgM positive } \\
\text { (serum); PCR } \\
\text { negative (CSF) } \\
\text { - taken on D9 } \\
\text { of illness }\end{array}$ & $\begin{array}{l}\text { Hyperintense } \\
\text { signals in the } \\
\text { right corona } \\
\text { radiata and left } \\
\text { frontal lobe } \\
\text { suggestive of } \\
\text { his previous } \\
\text { stroke }\end{array}$ & Normal & 34 days \\
\hline
\end{tabular}

Dengue cerebellitis can occur in any phase of dengue fever and is self-limiting. Further studies are required to elucidate its pathophysiology.

\section{Acknowledgements}

The author would like to thank the staff of the Neurology Unit, Department of Medicine, Universiti Kebangsaan Malaysia

\section{References:}

1. iDengue 2015. Available from: URL: http://idengue.remotesensing.gov.my/ idengue/index.php

2. Cheah WK, Ng KS, Marzilawati AR et al: A review of dengue research in Malaysia. Med J Malaysia, 2014; 69(A): 59-67

3. Gulati S, Maheshwari A: Atypical manifestations of dengue. Trop Med Int Health, 2007; 12(9): 1087-95

4. Carod-Artal FJ, Wichmann O, Farrar J, Gascón J: Neurological complications of dengue virus infection. Lancet Neurol, 2013; 12(9): 906-19
Medical Center and Dr Siti Soraya Ab Rahman, Radiologist, from the Islamic Science University of Malaysia for her work in interpreting the MRI images.

\section{Conflicts of interest}

None.

5. Weeratunga PN, Caldera HP, Gooneratne IK et al: Spontaneously resolving cerebellar syndrome as a sequelae of dengue viral infection: A case series from Sri Lanka. Pract Neurol, 2014; 14(3): 176-78

6. Withana M, Rodrigo C, Chang T et al: Dengue fever presenting with acute cerebellitis: A case report. BMC Res Notes, 2014; 7: 125

7. Sawaishi Y, Takada G: Acute cerebellitis. Cerebellum, 2002; 1: 223-28 